\title{
都市域の自然体験活動としてのミッパチプロジェクトに関する研究
}

\section{A study on honeybee projects as an activity to create chances to experience and enhance understanding of nature in an urban area}

\author{
山田 順之* 曽根 佑太* 古谷 勝則** \\ Yoriyuki YAMADA Yuta SONE Katsunori FURUYA
}

\begin{abstract}
In an era where half of the world's population lives in cities, biodiversity conservation in an urban area is a major global issue. Honeybee projects implemented in cities has increased its numbers recently, and they are thought to play a certain role for creating chances to experience nature and result to raising awareness of biodiversity. In this study, the purpose, contents of activity, and current status of domestic honeybee projects were researched to consider the most suitable environmental education program that enhances understanding of nature and enlightens biodiversity issues. The program was actually carried out in a honeybee project and the effect was examined by a consciousness survey that illustrates the change of ideas of local residents before and after the project. The survey revealed that the environmental education program resulted in change of impressions of the honeybee itself, enhanced the communication regarding nature, and raised the recognition of biodiversity. The 3 factors considered important for the realization of a successful and sustainable honeybee project were, the correct communication regarding safety issues, interactive activities such as observation of hive boxes, and creating chances to experience the value of ecological services such as the tasting of honey.
\end{abstract}

Keywords: biodiversity, honeybee project, environmental education, urban green, monitoring キーワード：生物多様性，ミッバチプロジェクト，環境教育，都市緑地，モニタリング

\section{1. はじめに}

都市域のビルの屋上などを利用して養蜂を実施する「ミツバチ プロジェクト」と名づけられた活動が都市域における自然体験や 自然の理解促進に結びつく取組みとしてマスメディアなどで頻繁 に紹介されるようになっている。ミツバチプロジェクトとは，個 人が自宅などで実施する趣味の養蜂や蜂蜜の採取を目的とする養 蜂業とは異なり，「都市域において，団体が実施する環境保全活動 などの目的を持つ継続的な養蜂プロジェクト」と位置付けること が出来る。この取組みはフランス・パリ市内で始まったといわれ ており1，現在でもエッフェル塔やオペラ座など 8 箇所で養蜂を 行いパリ産の蜂蜜として販売し人気を博している。国内では 2006 年の銀座ミツバチプロジェクトに始まり，都市域における自然と の触れ合い機会の創出や地域ブランディング手法として全国各地 に広まりつつある。ミツバチは，採䬺する際に植物の受粉を助け 植物の結実を支援する役割を担っている。また，都市域において 地産地消の蜂蜜やローヤルゼリー，蜜蝋を生産することが可能な ため，都市住民が自然の恵みである生態系サービスを体験する機 会を提供出来ると考えられており自然環境に関する理解促進効果 も期待されている1)。

一方，地球温暖化とならび生物多様性の保全への注目が高まつ ている2)3）この課題に関しては主に奥山・里山エリアでの貴重種 の保全活動などが議論されてきたが，世界の総人口の半数が都市 に住むようになった今日，多くの人が頻繁に自然の恵みを享受出 来る都市域における生物多様性の保全も今後益々重要になると指 摘されている4)。都市域の生物多様性の保全に関するアプローチ として, GIS を用いた計画論的手法5)や生物多様性の保全と不動 産価值との研究67) など経済便益の観点からの研究, また, 蝶や卜 ンボなどを指標とした学校ビオトープの利活用8)や自然環境教育 に関する研究例9)が知られている。ところが，トンボや蝶と比較 してミツバチを対象としたプロジェクトの事例研究や，その啓発
活動の効果について示唆したものは見受けられない。ミッバチプ ロジェクトは全国各地で展開されており, その活動内容も多様で あることが推察される。ミツバチプロジェクトが今後とも持続的 な取組みとして発展していくよう様々な方策を検討寸るためには, その多様な活動内容を把握する必要がある。さらに，特定生物種 の保全は人間の好き嫌いに大きく影響を受け10)，生物多様性保全 を目的として整備されたビオトープが，その重要性が認識されず に衰退している例も少なくないことが指摘されている11)。都市域 で生物多様性の保全を継続的に進めるためには，その生物を保全 する意味や生物多様性の重要性などを，地域に住む住民らに伝え ていくための自然体験活動や自然環境の理解促進活動が重要な課 題となっている。ミツバチを題材とした自然体験活動は，トンボ や蝶など実施例が多い他の生物種と異なり，危険な生き物と認識 され12)マイナスイメージがある一方で，蜂蜜などの自然の恵みを 直接的に体験でき，巣箱に生息するため実際に見たり触ったりす ることが可能であることなど独自性があるが，この特徴や課題に 関する研究事例はほとんど存在しない。

そこで，本研究ではまず，(1)国内で実施されているミツバチプ ロジェクトについて実施主体や活動内容などを把握しその活動実 態を明らかにする。次に，これら現状分析を踏まえ，(2)自然体験 活動としてのミツバチプロジェクトの環境教育プログラムを検討 しそれによる住民の意識変化を把握する。そして，(3)自然体験お よび自然環境への理解促進活動に資するミツバチプロジェクトの 方向性について考察することを目的とする。

\section{2. 本研究の内容と方法}

研究の手順を図一 1 に示す。まず，全国各地で実施されている ミツバチプロジェクトの多様な活動内容を把握するため, 新聞記 事検索を利用して全国のミツバチプロジェクトを調查し, 広報資 料やヒアリング調査などにより，プロジェクトの開始年月，実施

*鹿島建設株式会社環境本部㤦千葉大学大学院園芸学研究科 
主体，巣箱の設置場所，飼育ミツバチ種類などの概要を把握する とともに，実際のミツバチプロジェクトの活動内容からプロジェ クトの特徴を分析し, 具体的成果や課題として示される事項を取 りまとめた。次に,ミツバチを用いた自然体験活動を研究するた め, 上記事例研究で得た知見を基にミツバチの特徵を用いた環境 教育プログラムの内容検討を行うとともに, 周辺の緑地モニタリ ング調査と調查結果のプログラムへの反映を行いながら，地域住 民である未就学児童とその保護者を対象とした環境教育を実施し た。環境教育プログラムについてはアンケート調査を実施し，ミ ツバチの危険性，自然環境に関する意識の変化や理解促進効果を 明らかにした。最後に，得られた知見を基に自然体験および自然 環境への理解促進活動に資するミツバチプロジェクトの方向性を 考察した。

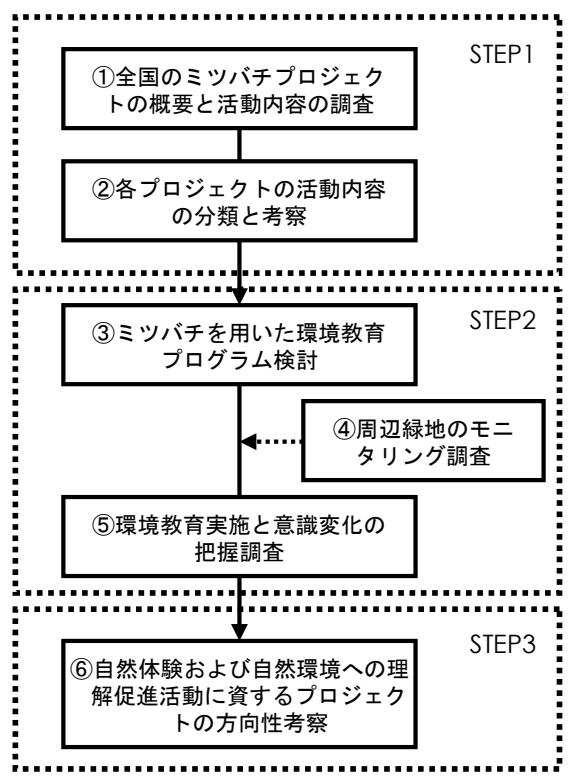

図-1 研究の手順

\section{3. ミツバチプロジェクトの概要と活動内容}

\section{（1）調査方法}

都市域のミツバチプロジェクトの実態を調査するため, 新聞の 全文記事検索により国内のプロジェクトを把握することとした。 検索ツールは全国紙，一般紙，専門紙など 141 紙を対象としてい る日経テレコン 21 を利用し，「ミツバチプロジェクト」をキーワ ードとした検索を実施した。検索対象期間は，国内のミツバチプ ロジェクトの先駆けとなった銀座ミツバチプロジェクトの開始年 が 2006 年のため, 2006 年 1 月 1 日から 2010 年 6 月 30 日まで の 4 年と 6 力月とした。検索の結果, 2006 年 : 9 件, 2007 年 : 28 件, 2008 年: 36 件, 2009 年: 69 件, 2010 年 : 52 件の計 194 件の記事が確認された。この中から一種のイベントとして一時的 に実施された取組みや実施内容の確認できない事例を除き，現在 継続的に実施されている 20 件のプロジェクトを抽出した。これ らプロジェクトの該当記事に加えて, 各プロジェクトの広報資料 の調查や関係者に対するヒアリングを行い, 巣箱の設置場所, 実 施主体，飼育しているミツバチの種類，活動内容などについて調 查分析を行った。

\section{（2）調査結果および考察}

1）実施地域と実施主体

調査結果を表一 1 に示す。実施地域については，北は北海道か ら南は九州まで全国に分布しており，実施件数は東京都 23 区内 が 9 件で最多, 次いで名古屋市内が 3 件となっていることが示さ れた。実施主体はNPO 法人が 4 件，学校法人が 3 件，企業が 4 件など多様であり, 団体規模も様々な主体が関与していることが 明らかになった。プロジェクト数は 2006 年に 1 件であったが, 2009 年に新たに 8 件， 2010 年には新たに 10 件のプロジェクト が開始されたことが確認できた。これにより国内の取組み件数が 近年急増していることが判明した。

2）巣箱設置場所と飼育種

巣箱は全てがビルや倉庫の屋上など高い位置に設置していた。 この理由として，設置スペース確保や空中を移動するミツバチの 行動特性 ${ }^{1)}$ に加え, 人口の密集する都市域における安全性の確保 のため, ミツバチと人間の動線を交わりにくくする目的が推察さ れる。国内で飼育可能なミツバチは, セイヨウミツバチ (Apis

表-1 本研究で対象とした日本国内のミツバチプロジェクト

\begin{tabular}{|c|c|c|c|c|c|c|c|c|c|c|c|}
\hline & \multirow[b]{2}{*}{ プロジェクト名 } & \multirow[b]{2}{*}{ 開始時期 } & \multirow[b]{2}{*}{ 実施地域 } & \multirow[b]{2}{*}{ 巣箱設置場所 } & \multirow[b]{2}{*}{ 実施主体 } & \multicolumn{2}{|c|}{ 蜂の種類 } & \multicolumn{4}{|c|}{ 活動内容 } \\
\hline & & & & & & $\begin{array}{c}\text { セイヨウミ } \\
\text { ツバチ }\end{array}$ & \begin{tabular}{|c|} 
ニホンミツ \\
バチ
\end{tabular} & 環境教育 & 地域ブランド開発 & 緑化促進 & 蜜源調查 \\
\hline 1 & 銀座ミツバチプロジェクト & 2006年3月 & 東京都中央区 & ビル屋上 & NPO法人 & - & - & フォーラム開催など & ハチミツカクテルなど & ビーガーデン整備支援 & 周辺蜜源マップ作成 \\
\hline 2 & 中延シツバチプロジェクト & 2008年4月 & 東京都品川区 & ビル屋上 & NPO法人 & & घ & & 羊美など & & \\
\hline 3 & 養蜂プロジェタト & 2008年10月 & 東京都板橋区 & 校舎屋上 & 学校法人 & & - & 近隣小学校生対象 & 地域ブランド商品開発 & & \\
\hline 4 & HAMA Boom! Boom! プロジェクト & 2009年2月 & 神奈川県横浜市 & 倉庫屋上 & 企業 & घ & & 大学や高校と連携 & 横浜ブランド商品開発 & & \\
\hline 5 & おかバチプロジェクト & 2009年3月 & 東京都世田谷区 & ビル屋上 & 商店街 & - & & 大学と連携 & スイーツなど & 自由が丘森林化計画 & \\
\hline 6 & 山の都ハニープロジェクト & 2009年3月 & 山梨県甲府市 & 駅屋上など & 青年会議所 & $\mathbf{\square}$ & - & & スイーツなど & マイはち(鉢) 運動 & \\
\hline 7 & おおいたミシバチプロジェクト & 2009年4月 & 大分県大分市 & ビル屋上 & NPO法人 & - & & & スイーツなど & & \\
\hline 8 & ニホンミツバチプロジェクト & 2009年5月 & 東京都豊島区 & 社宅屋上 & 企業 & & - & 幼稚園児対象 & & & 定期的なモニ夘ング \\
\hline 9 & 日本橋ミツバチ・サロン & 2009年6月 & 東京都中央区 & ビル屋上 & 企業 & & - & 定期的な見学会 & & & \\
\hline 10 & 戸田ミツバチプロジェクト & 2009年7月 & 埼玉県戸田市 & ビル屋上 & 商工会女性部 & 口 & & & 戸田ブランド商品開発 & & \\
\hline 11 & 江古田ミツバチプロジェクト & 2010年3月 & 東京都練馬区 & 校舎屋上 & 任意団体 & - & & 定期的な見学会 & 商店街と連携 & 花いっぱい運動 & 周辺蜜源の写真撮影 \\
\hline 12 & 名古屋·栄ニホンミッバチプロジェタト & 2010年3月 & 愛知県名古屋市 & ビル屋上 & 企業 & & - & 幼稚園や社員対象 & 地元の木テルと連携 & & 定期的なモニ㚈ング \\
\hline 13 & 大倉山商店街ミッバチプロジェタト & 2010年3月 & 神奈川県横浜市 & ビル屋上 & 建設協会 & - & & & 洋菓子など & & \\
\hline 14 & マルハチプロジェクト & 2010年4月 & 摠知県名古屋市 & ビル屋上 & NPO法人 & - & 口 & 各種見学会 & 洋菓子など & 久屋大通りの緑化 & \\
\hline 15 & 日駒二ホンミツバチプロジェクト & 2010年4月 & 東京都目黒区 & 校舎屋上 & 学校法人 & & - & 中高生対象 & & ビーガーデン整備 & \\
\hline 16 & 仙台ミツバチプロジェクト & 2010年4月 & 宮城県仙台市 & ビル屋上 & 任意団体 & & - & & & & \\
\hline 17 & いわき勿来ミツバチプロジェクト & 2010年5月 & 福島県いわき市 & ビル屋上 & 任意団体 & - & & 見学会也講演会 & & 種や苗の配布 & \\
\hline 18 & サッポロミツバチプロジェクト & 2010年5月 & 北海道札幌市 & ビル屋上 & 任意団体 & - & & 見学会也講演会 & スイーツなど & 屋上菜園 & 周辺蜜源の写真撮影 \\
\hline 19 & 名古屋学院大学ミツバチプロジェクト & 2010年6月 & 愛知県名古屋市 & 校舎屋上 & 学校法人 & & - & 出前授業など & ハチミツクリームこっぺ & 園児と苗植え & 周辺蜜源マップ作成 \\
\hline 20 & すみだ百花蜜プロジェクト & 2010年6月 & 東京都墨田区 & 校舎屋上 & 任意団体 & & - & & & & 周辺蜜源の写真撮影 \\
\hline & ※1プロジェクトの並び順は開始時 & 頁である。 & ※2( )内は全 & こ占める割 & & & & 13 件 $(65 \%)$ & 14 件 $(70 \%)$ & 9件 ( $45 \%)$ & 7件 (35\%) \\
\hline
\end{tabular}


mellifera) とトウヨウミツバチ (Apis cerana) の一亜種である ニホンミツバチ (Apis cerana japonica Rad) の二種である。こ の二種では採蜜量ではセイヨウミツバチが，病気や気候への而性 ではニホンミツバチが優れており, 飼育方法も異なっている。従 来の養蜂業では採蜜量に勝るセイヨウミツバチの飼育が大部分で あったが，近年では生物多様性への関心の高まりを受け日本の在 来種であるニホンミツバチへの関心も高まっている13)。今回の調 査では，セイヨウミツバチが 11 件，二ホンミツバチが 12 件で飼 育され，両方飼育しているプロジェクトが 3 件あった。採蜜量が 少ないニホンミツバチを採用した理由としては，在来種であるこ とやセイヨウミツバチよりも日本国内で古くから養蜂されていた こと，性格が温厚であることなどが理由とされている。

3）プロジェクトの活動内容の分類

活動内容に関する調査データを分析した結果，採蜜体験や講習 会などを開く「環境教育」, 採取した蜂蜜を使った「地域ブランド 開発」, 周辺の緑化の啓発や緑化活動を行う「緑化促進」, そして 周辺の蜜源マップ作成などを行う「蜜源調査」の 4 つに分類する ことが出来た。以下に各活動内容について詳述する。

(a)環境教育

環境教育は，ミツバチの生態を観察するための見学会，自然の めぐみを体験する採蜜体験, 講師を招いた講習会や勉強会, 周辺 の教育機関に出向く出前授業など様々な取組みが見られる。学生 を対象とした見学会を開いているプロジェクトや児童を対象とし た授業を実施しているプロジェクト，さらには幅広い年齢層を対 象とした体験会など 13 件の取組みがあった。プロジェクトの概 要や目的を説明する際，ミツバチがどのように環境や人間の生活 に対して貢献しているのか，また，ミツバチはどのような生き物 なのかを伝える初歩的レベルの環境教育は多くのプロジェクトで 実施しており，実際のミツバチを観察出来る見学会に関しては半 分以上のプロジェクトが実施している。さらに, ミツバチを通し て都市環境を考える一歩進んだ環境教育を実施する主体もあり， 都市と生物多様性に関する継続的な教育プログラムの提供や環境 分野の専門家を招いたフォーラムを実施しているプロジェクトも 存在している。

(b)地域ブランド開発

地域ブランド開発の取組みは，採取した蜂蜜を用いて地産地消 の商品を作成しているケースが多く，地域の蜂蜜のブランド化， 商店街への提供など 14 件が確認できた。おが゙チプロジェクト では地元菓子店の協力を得て自由が丘ブランドのスイーツを開発 している。サッポロミツバチプロジェクトも都心部で採れた蜂蜜 による様々な商品開発に力を入れており，ブランドづくりサポー ターを募集している。

(c)緑化促進

緑化促進は，周辺の蜜源植物を増やしミツバチの生育環境を向 上させること，花と緑あふれる豊かな環境の創造を目的としてい る。例えば，山の都ハニープロジェクトの「マイはち(鉢) 運動」 や，周辺のビルに対して新たな蜜源となる屋上緑化の支援を行っ ている銀座ミツバチプロジェクトの「Bee Garden」など，9件の プロジェクトで目的として設定されている。ただし，緑地の整備 を推進するなど実際の緑化活動を実施しているプロジェクトは現 時点では限定的であり, 緑化啓発運動にとどまっている取組みも 多く, 今後の課題となると思われる。

(d)蜜源調査

緑化促進などを通して蜜源植物の保全に言及しているプロジェ クトが多数を占めているにもかかわらず，実際に蜜源調査を実施 しているプロジェクトは比較的少ない。その活動も，周辺の緑地 においてミツバチが訪花している蜜源植物の写真をブログに掲載 する取組みから，GPS による蜜源の位置情報を収集して解析す
る取組みなど濃淡があり，7 件のプロジェクトで実施されている。 周辺の緑とのつながりを意識したプロジェクトが多い中, 蜜源調 查は重要な目的となるはずだが，実際はミツバチの飼育や他の活 動内容の人的負担が大きく, 思うように実施できていないのが現 状と推察される。

4) ミツバチプロジェクトの活動内容の考察

一般にミツバチプロジェクトの目的は蜂蜜の採取が大部分を占 めると考えられているが，上記の分類結果から単に蜂蜜採取のみ を実施するのではなく, 自然と人間の関わりについて考えるきっ かけを創出する啓発活動や，実際の環境改善に結びつく緑化活動 を実施する広がりのある多様な取組みが確認できた。例えば蜜源 調査を実施しているプロジェクトでは，都市域においてミツバチ がごのような植物から採䬣しているのか定量的なデータを収集し ており，ミツバチの視点から都市緑地の機能を明らかに出来る活 動内容と捉えることが出来る。また, 安全で質の高い蜂蜜を採取 するために地域の緑化を質, 量ともに改善し, 管理手法にも配慮 が必要なことを一般にも理解しや寸く啓発することで都市域の緑 化活動を間接的に推進している取組みも見られた。一方，地域ブ ランド開発が活動内容に入っていない 6 件のプロジェクトのうち 4 件は環境教育や蜜源調査に力を入れていることから, 各実施主 体の目的に応じてミツバチプロジェクトの活動内容に大きな差異 が出ていることが確認できた。これらの調査分析により，ミツバ チプロジェクトの特徴や狙い，人と自然との関わりの再構築や地 域活性化などの具体的な活動内容が明らかになった。特に $65 \%$ の プロジェクトで活動内容とされている環境教育に関しては, 幅広 い受講者を対象として見学会などの初歩的レベルから専門的なレ ベルまで多様な取組みが確認できた。ここで得られた知見を参考 にし，次にミツバチを用いた環境教育プログラムの検討と，それ による住民意識変化の把握調査を実施した。

\section{4.ミツバチを用いた自然体験活動とそれによる意識変化の調査 (1) 環境教育プログラムの検討}

上記の調査結果により，ミツバチプロジェクトへの取組みが増 加していること，都市住民が自然との触れ合い活動を行う多様な 機会を創出していることが確認できた。また, 蜂蜜など生態系サ 一ビスを直接的に体験出来ること，見学会などによって見たり触 ったり出来るなどの特徴を有するため, ミツバチを用いた環境教 育は, 都市域における自然環境への理解を促進する効果が高いの ではないかと考えた。一方，今後ミツバチプロジェクトを進める 上での課題として，近隣に巣があると刺されるというミツバチの 安全性に対する誤解 4 )があり, 適切な環境教育を実施することで, 生物との付き合い方に対する正しい理解が促進されると考えた。

そこで，都心に近く全国第 2 位の人口密集地区である東京都豊 島区 (人口密度 : 20,107 人 $/ \mathrm{km}^{2}$, 平成 21 年度) で実施している ミツバチプロジェクトにおいて，ミツバチを題材とした自然環境 への理解促進活動として環境教育を実施し, 意識変化を把握調査 することとした。ここでは, 地域住民に対してミツバチの行動や まちづくりとの関係を説明する環境教育を実施するとともに，近 隣の览童館に通園する未就学览に対して，ミツバチを題材にした 環境教育を計 5 回行った（表一2）。なお，当該地域には周辺にビ オトープなどが存在せず，実際の生き物に触れる機会が他の地域 よりも少ない状況であり，トンボや蝶など他の生物を用いた環境 教育の実施は困難な状況であった。プログラムに関しては, 生態 系の専門家および览童館教員と協議して作成し, 就学前の児童が ミツバチや緑などの自然環境を十分に理解出来るよう実体験を含 む内容とした。具体的にはミツバチプロジェクトの特徵である採 蜜体験や蜂蜜の試食, 巣箱の見学などを盛り込んだ。さらに, 巣 箱周辺地域の緑地をモニタリング調查し，地域の訪花植物情報な 
どを教育プログラムに盛り込み，周辺に実在する自然環境への関 心を高める工夫を行った。これにより，日常自然と触れ合う機会 が少なく，立地条件から生き物を用いた環境教育プログラムを適 用することが困難な当該地区住民に対する自然環境の理解促進に 結びつくと考えた。また, 毎回プログラム終了時に,「お家の人に 今日のお話を報告してくださいり付け加え親子の会話を促した。

\section{表一2 環境教育プログラム}

第一回 : ミツバチの種類
第二回 : ミツバチの働き（受粉など）
第三回 : 巣箱見学と採蜜
第四回 : ミツバチの巣の構造（図一2参照）
第五回 : ミツバチの䘕動
その他 : 近隣住民を対象とした環境教育を1 回実施

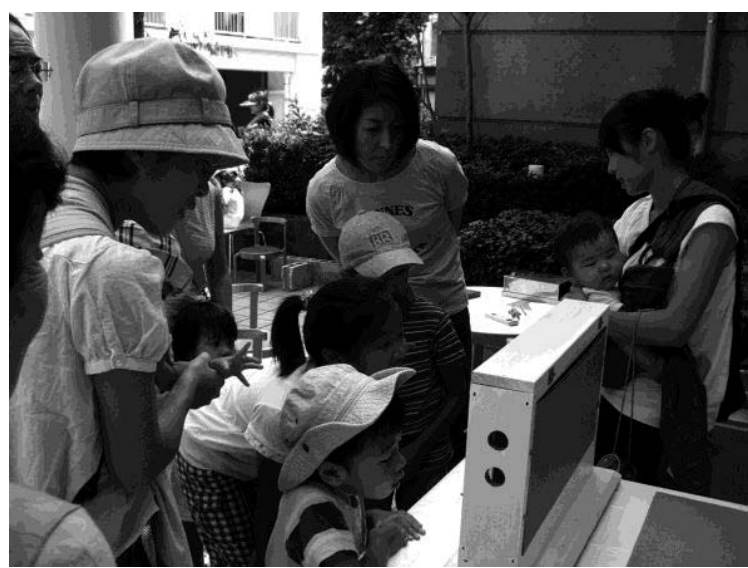

図一2 環境教育プログラムの実施状況（ミツバチの巣の観察）

\section{（2）周辺緑地モニタリング調査}

\section{1）調查方法}

研究対象としたプロジェクトで飼育しているニホンミツバチの 主な行動範囲は巣箱から半径約 $2 \mathrm{~km}$ といわれている13)。よって, 巣箱から半径 $2.0 \mathrm{~km}$, 面積約 $12.56 \mathrm{~km}^{2}$ の範囲を調查範囲と設定 し，このエリアの南東部，南西部，北東部，北西部にそれぞれ約 $40 \mathrm{~km}$ のラインを計 4 ルート設定し，自転車で走行しながら蜜源 植物を確認し随時双眼鏡などで観察を行った。位置の測定には携 帯型 GPS（EMPEX，ポケナビミニ）を利用し，2009 年 7 月末 から 12 月までの間に計 13 回の調査を実施した。

2) 調查結果および考察

設置した巣箱から飛来したミツバチであるかどうかを確認する ため，任意のサンプルを定め適宜ミツバチの飛来方向を目視によ り確認したところ，全て巣箱設置方向からの飛来であったこと， また，行政機関や近隣へのヒアリングにおいても周囲でニホンミ ツバチが生息している情報が確認できなかったことから，今回の モニタリングで観察したニホンミツバチの大部分がプロジェクト で設置している巣箱から飛来したミツバチであると考えられる。 計 13 回の調査で実際にニホンミツバチが訪花していたのは 269 箇所であった（図-3）。また，本モニタリング調査で，訪花が確 認された蜜源植物 20 種を表一 3 に示す。一般に良く知られている 蜜源植物である, ネズミモチやトチノキ，ユリノキ13)は花期がず れていたため訪花を確認することは出来なかった。これら実際に ニホンミツバチの蜜源となった植物は，230 箇所 (85.5\%) が民有 地の小さな緑であった。その他，公園は 17 箇所 $(6.3 \%)$, 学校や 病院，街路樹などが 22 箇所 $(8.2 \%)$ となっていた。図一 4 に示寸 訪花した植物の樹高データを見ても $4 \mathrm{~m}$ 程度の植栽が中心であり, このエリアでは民有地の小規模な緑が貴重な蜜源として機能して
いることが示唆された。このようにして得た地域の蜜源植物など の緑地モニタリングデータを毎回の環境教育プログラムの中で紹 介し，参加者にとって身近な自然に結びつく話題の提供を心掛け た。

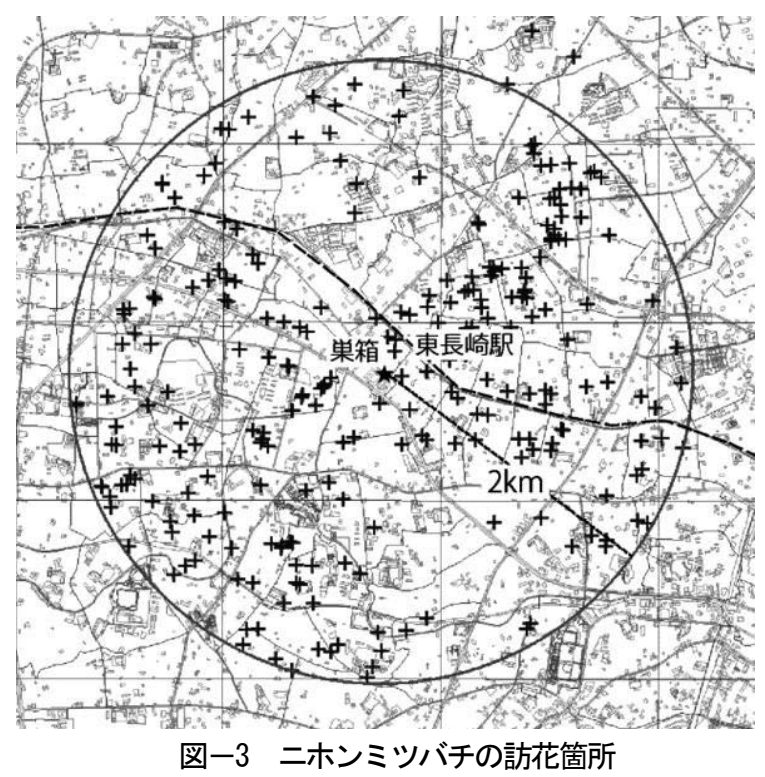

表一3 訪花か確認された植物

ルリマツリ, ポーチュラカ, マツバボタン, エンジュ, カクレミノ,
ノウゼンカズラ, ノブドウ, ヘチマ, サルスベリ, ヤブガラシ,
メツルソバ, タラノキ, キンモクセイ, シソ, シャクチリソバ, セ
イタカアワダチソウ, キヅタ, ビワ, サザンカ, コセンダングサ

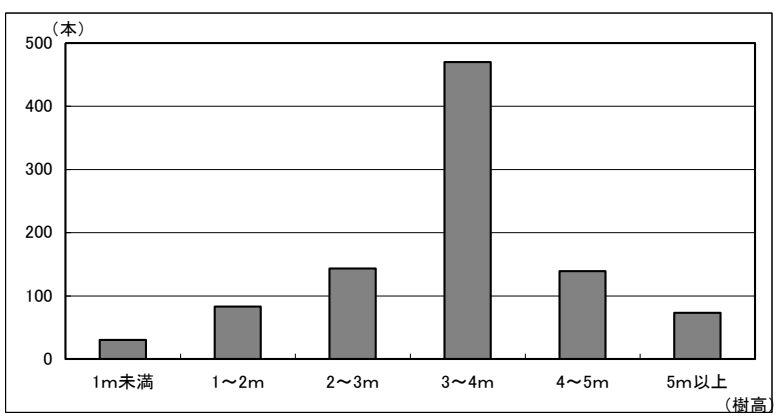

図ー4＼cjkstart訪花か確認された樹木の樹高

\section{（3）住民の意識変化の把握調査}

1) 調査方法

環境教育の受講の前後で住民のミツバチや自然環境への意識が どのように変化するのか環境教育の自然環境の理解促進効果を把 握することを目的としてアンケート調査を実施した。

第一回目は，地域住民を対象とした環境教育実施日（2009 年 8 月 25 日）に環境教育受講者を対象として実施し 32 票の回収を得 て有効回収は 30 票であった。また, 第二回目の調査は, 未就学 児の保護者に 5 回の環境教育が終了した 1 週間後の同年 11 月 6 日に実施し，27 票を回収し有効回収は 27 票であった。なお，ア ンケートの実施を 1 週間遅らせたのは, 児童と保護者とのコミュ ニケーションに一定の日数を要することを考慮したためである。

2) 調査結果

(a)ミツバチの安全性

当該地区ではミツバチの飼育を開始する前に地域住民に対して 説明を行っている。説明方法は掲示板に A3 版の大きさで作成し た説明文を掲示し，ミツバチは飛行動線が人の動線と交わりにく 
いこと，こちらから危害を加えない限り刺すことはないことを説 明している。調査結果 (図一5) から,プロジェクト開始前に, “八 チは刺すこともあるので危険だ”と回答した方が 18 人 (約 $32 \%$ ) いたが，環境教育実施後は 0 人になった。一方，“こちらから危 害を加えない限り問題ない”“危険性は感じない”が実施後にあわ せて 22 人増えたことが示された。これらプロジェクト実施前後 の回答をサイン検定により検証した結果，住民のとらえ方に有意 な差があることがわかった $(\mathrm{P}$ 值 $<0.01)$ 。プロジェクト開始前には ミツバチの危険性を感じていた地域住民が約 3 割いたが，環境教 育の実施により住民のミツバチが危険という意識が低下したこと がわかる。この理由として，ミツバチの飼育開始後に実際に危険 性を感じることがなかった事，プロジェクトが新聞報道などに取 り上げられイメージが向上したこと，また，環境教育により正確 な情報を得ることが出来ミツバチに関する理解が深まった事など が考えられる。

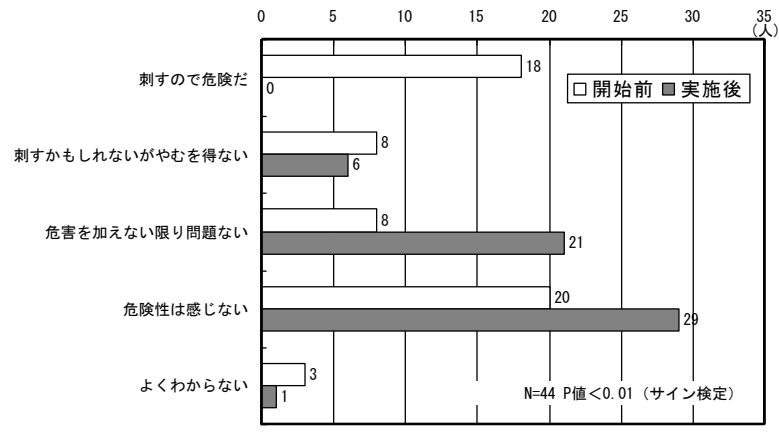

(b)自然との触れ合い

未就学览に対寸る環境教育の効果を測るため，緑や自然環境に 関する会話の有無，緑や自然環境に関する関心の程度をアンケー トにより調査した（図－6，7）。就学前の児童本人がアンケート に回答することは困難であるため，調査はその保護者に対して実 施した。これは，保護者に対する間接的な教育効果を測定する狙 いもある。

自然に関する会話の有無では，プロジェクト開始前に“まった く会話に出ない”が 3 人いたのに対し環境教育実施後には 0 人に, “ほとんど会話に出ない”が 8 人から 2 人に減少した。一方，“よ く会話に出る”が 1 人から 7 人に, “たまに会話に出る”が 13 人 から 16 人に環境教育実施後に増加した。実施前後の回答をサイ ン検定により検証した結果, 有意差が得られたため $(\mathrm{P}$ 值く 0.01$)$, 環境教育の実施により自然に関する会話が増加したことがわかる。 この要因としてこのエリアでは身近に自然が少ないため自然と触 れ合う実体験の機会がそしく, 結果として関連する会話が少なく なっていることが推察される。また，環境教育実施後に自然環境 に関連する会話が増えていることから，ミツバチを題材とした環 境教育活動は未就学児の自然環境に関する啓発に対して一定の効 果が期待出来ると考える。特に，今回の環境教育では「四つ角に あるサルスベリにミツバチが来ていた」などモニタリング調査で 得た訪花植物の情報を具体的かつタイムリーに紹介したため，そ の教育効果が一層強化されたものと推察する。

同様に，保護者の目から見た児童の行動の項目では環境教育実 施前に, “強い関心を示す” (3 人), “関心を示す” (14 人) に対 して, “あまり関心を示さない” $(7$ 人), “関心がない” $(0$ 人) と いう状況であったが，実施後に，“あまり関心を示さない”と“関 心がない”がともに 0 人となった。実施前後の回答をサイン検定 により検証した結果, 有意差が得られたため $(\mathrm{P}$ 值 $<0.01)$, 環境教
育実施後に児童の自然に関する関心が高まったと解釈できる。こ れは，自然と接する機会が少ないためにあまり関心を示さなかっ た览童が，モニタリング調査データからの具体的な環境情報が提 供され，さらに体験型のプログラムにより自然と触れ合う機会を 得ることが出来たためと考えられる。
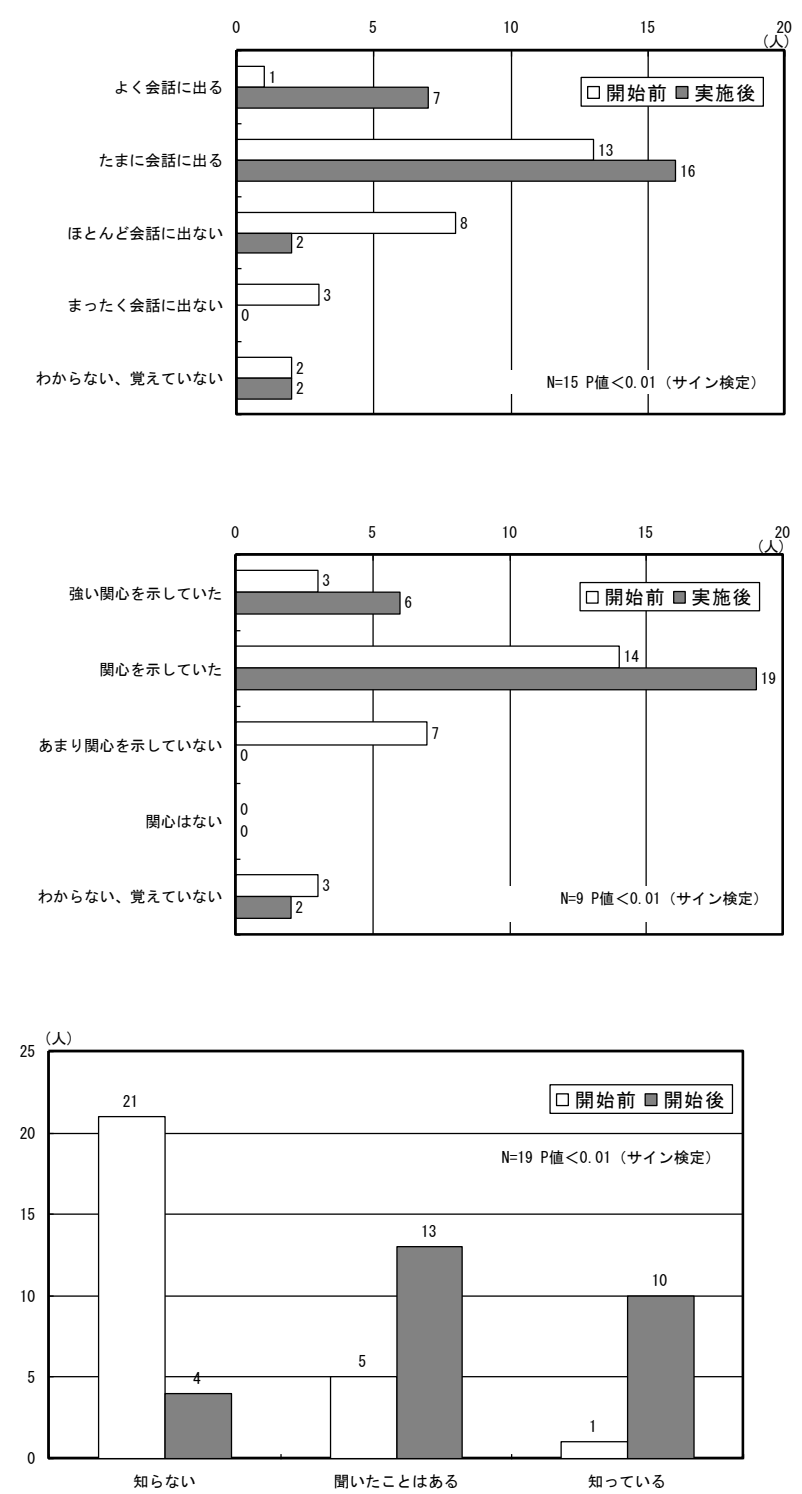

(c)自然環境の理解促進と生物多様性への認識

今回の環境教育では, 事例研究で把握したミツバチプロジェク トの特徴を生かし, 周辺緑地モニタリング結果のプログラムへの 反映, 巣箱の見学, 地元産の蜂蜜を味わう体験などにより自然環 境への興味を促し生物多様性の認識に影響するような工夫を行っ ている。生物多様性の認知度は平成 21 年に内閣府が実施した最 新の調査 ${ }^{15)}$ によると, “言葉の意味を知っている”と答えた者の割 合が $12.8 \%$ ，“意味は知らないが，言葉は聞いたことがある”と答 えた者の割合が $23.6 \%$ ，合計 $36.4 \%$ となっている。一方，“聞いた こともない”と答えた者の割合が $61.5 \%$ となている。第三次生 物多様性国家戦略では，この認知度を $50 \%$ 以上とする数值目標が 掲げられ課題となっているため，ミツバチプロジェクトの実施に よる認知度の変化を把握することとした（図一8）。プロジェクト 開始前の状況は，生物多様性という言葉を “知っている”, “聞い たことがある”あわせて 6 人 $(22 \%)$ であり，“知らない”と回答 
した人が 21 人 $(78 \%)$ であった。ところが実施後には, “知って いる” 10 人 $(37 \%)$, “聞いたことがある” 13 人 $(48 \%)$, “知らな い” 4 人 $(15 \%)$ という結果が示された。実施前後の回答をサイン 検定により検証した結果，有意な差があることがわかった(P 值 く0.01)。生物多様性はその概念が広域にわたるため言葉が浸透し にくい状況にあるが，都市域においても生物多様性の支える生態 系サービスを実感出来るミツバチプロジェクトという具体的活動 が，自然環境の理解促進とそれによる生物多様性の認知度向上に つながっていることが推察された。

\section{5. 自然体験活動に資するプロジェクトの方向性}

意識変化の把握調査結果に基づき，自然体験および自然環境へ の理解促進活動に資するミツバチプロジェクトの方向性に関する 考察を行った。

\section{（1）危険性に関する意識}

ミツバチプロジェクトを持続的に実施するためには，都市域で ミツバチを飼育することが危険な行為であるとの周辺住民の認識 を改善していく必要がある。今回実施した環境教育プログラムは ミツバチの危険性に関して正しい認識を与えることに一定の効果 が見られた。よって，今後のプロジェクト運営においては，都市 域での生物との共生に留意し, 正確な情報を適切に伝える環境教 育プログラムの提供が期待される。

\section{（2）触れ合い機会の創出}

ミツバチプロジェクトは，見学会などを実施することで多くの 住民に生き物との触れ合い機会を創出することが可能である。ま た, そのような取組みにより, 自然に関する親子の会話が増加し, 未就学児の自然環境に関する関心が高まる傾向があることが本研 究で判明した。よって, 環境教育実施に際しては講演会などによ る情報提供だけでなく，巣箱見学など触れ合い機会を創出し理解 促進効果を高めていくことが求められる。

\section{（3）生態系サービスの顕在化}

ミツバチプロジェクトは, 地元産の蜂蜜の提供により生態系サ ービスをわかりやすく認識できる点が優れた特徴として挙げられ る。また，今回実施した緑地モニタリングにより蜂蜜の供給源と なる周辺緑地に関する情報を提供でき, 結果として環境教育プロ グラム受講者の自然環境に関寸る関心を高めていることが意識調 查から推察される。蜜源調査などの緑地モニタリングを実施して いるプロジェクトはまだ全体の $35 \%$ 程度であるが，自然環境の理 解促進活動という観点から今後取組みの必要性がさらに高くなる と考えられる。

\section{6. まとめと今後の課題}

近年増加しているミツバチプロジェクトは自然体験活動に結び つく取組みと期待されているが，その活動実態は明らかにされて いない。また，危険性に関する誤解がありプロジェクト実施の課 題となっている。さらに, 自然環境の理解促進活動の観点からプ ロジェクトのあり方を議論することも持続的な取組みとして発展 するために求められる。本研究ではこのような問題意識に立ち, ミツバチプロジェクトの概要と活動内容を調査分類するとともに, 自然環境の理解促進の視点から地域住民に対するミツバチを題材 とした環境教育プログラムを検討, 提供しその意識変化の把握調 査を行った。主な成果は次の通りである。

\section{（1）ミツバチプロジェクトの概要と活動内容}

国内におけるミツバチプロジェクトは 20 件確認でき 2006 年に 開始し 2009 年度以降に急増しており, 実施エリアは東京 23 区内 が約半数であるが，北海道から大分まで全国的に実施されている こと，事業主体は NPO 法人だけでなく，学校，企業など多様な 主体が参加していることが確認できた。その活動内容目的は，単
なる蜂蜜の採取ではなく, 環境教育, 地域ブランド開発，緑化促 進，蜜源調査の 4 つのタイプに分類できた。

\section{（2）ミツバチを用いた自然体験活動と意識変化の調査}

ミツバチのイメージに関しては約半数の住民が危険性を心配し ていたが，適切な環境教育により大部分の住民がミツバチの飼育 に理解を示寸ようになった。さらに，モニタリング調査で得た都 市緑地の情報を環境教育に用いることにより，親子間における自 然に関する会話の増加や未就学児の自然環境への関心の高まりが 見られることが環境教育プログラム実施前後のアンケート調查に より明らかになった。加えて，ミツバチという身近な生き物から 得る蜂蜜などの自然の恵みを認識することにより，生物多様性に 関する認知度が向上することが示唆された。

\section{（3）自然体験活動に資するプロジェクトの方向性}

プロジェクトの継続的な実施については，危険性に関する意識 を改善するための環境教育により地域住民の理解を得ることが重 要であり, さらに自然環境の理解促進という視点で持続的にプロ ジェクトを発展させるために巣箱見学など触れ合い機会の創出, 地元産の蜂蜜の提供や周辺緑地のモニタリング結果の環境教育へ の反映などが重要になると考えられた。

\section{(4) 今後の課題}

本研究ではミツバチプロジェクトの実態を明らかにするととも に，その一環として実施する環境教育が都市域の自然環境の理解 促進効果など一定の役割を果たしていることを明らかにした。こ の知見は自然体験活動としてミツバチプロジェクトを導入する際 の検討材料となると考える。また，自然体験は生物多様性の啓発 活動につながるため，これらの活動が都市域の生物多様性保全に 貢献できる可能性は高いと考える。今後の課題として，トンボや 蝶など他の保全活動との比較調査, 継続的な環境教育プログラム の実施による効果の検証などが求められる。

\section{参考 · 引用文献}

1）山田順之 (2010) : ニホンミツバチプロジェクト : アーバン・アドバン ス $52,40-46$

2）環境省（2009）: 環境白書・循環型社会白書・生物多様性白書 : 環境省, 400pp

3）環境省（2009）: 生物多様性民間参画ガイドライン：環境省，133pp

4) 熟谷いずみ (2010) : 湿地再生と生物多様性に富む地域づくり :CEL92, 34-37

5）山田順之・上田純広・恒川篤史(2003）：GIS を活用した緑地の環境保全 機能の評価一静岡県掛川市を例としてー: GIS一理論と応用 11(1) 61-69

6) KUMAGAI, Yoichi·YAMADA, Yoriyuki (2008) :Green space relations with residential values in downtown Tokyo-implications for urban biodiversity conservation : Local Environment 13(2), 141-157

7) 伊藤雅人 (2005)：不動産に関する「環境付加価値」の検討：(社) 東京都 不動産鑑定士協会設立 10 周年記念論文, 17-18

8）㠃山洋志・上甫木昭春·佐藤治雄(2002) : チョウとトンボの行動から捉え た学校ビオトープのあり方に関する研究 : ランドスケープ研究 65 (5), 507-512

9）大越美香・熊谷洋一 (2002) : 学校ビオトープと緑地の自然環境教育的 利用に関する研究 : ランドスケープ研究 65(5), 743-746

10) 谷口守・松中亮治・山本悠二 (2008) : 今後の生物多様性保全策の検討 材料としての特定生物種保全の実態分析一人間の「好き嫌い」と地域 特性に着目して一: 都市計画論文集 43(1)，60-65

11) 水口達也・安藤秀俊 (2007) : 福岡市内の小学校における学校ビオトー プの調查 : 科教研報 22(1), 111-116

12）杉浦明平 (1995)：養蜂記 : 中央公論社, $279 p p$

13）日本在来種みつばちの会（2000）: 日本ミツバチ:農文協，175pp

14）田中淳夫 (2009) : 銀座ミツバチ物語一美味しい景観づくりのススメ： 時事通信出版局, 199pp

15）内閣府大臣官房政府広報室（2009）: 環境問題に関する世論調査 : 内閣 府 